\title{
Supra-Citizen \& Sub-Citizen: Subjects at the Border
}

\author{
Jennifer Hyndman
}

\section{Supra-citoyens et sub-citoyens: Sujets à la frontière}

Ce texte met en lumière la rature de certaines positions de sujet liées à la condition d'apatride, plus particulièrement celle des femmes vivant dans les camps de réfugiés installés le long de la frontière entre le Kenya et la Somalie. Hyndman y analyse le discours de l'aide humanitaire internationale de l'HCNUR; elle s'offre comme intermédiaire du discours des réfugiées et elle recontextualise un poème écrit par une travailleuse sociale qui oeuvre dans les camps. A partir des notions de sujet et d'abject de Judith Butler, elle explore les relations qui existent entre ceux/celles qui comptent (supra-citoyens/nes) et ceux/celles qui comptent à peine(subcitoyens/nes).

In the Library of Congress cataloguing system, 'migration' falls between 'immigration' and 'colonialism' (Bammer xviii), a kind of displacement of nation. Forced migration is a more acute relation of power which involves the re-negotiation and sometimes relocation of nation. For stateless subjects seeking asylum, gendered inscriptions of cultural and institutional practice are part of writing the nation in refugee camps along the Kenya-Somalia border. My project here is to expose the erasure of certain subject positions linked to statelessness, particularly those of women refugees who live in the geographic, political, and discursive border areas of the nation. I aim to reinscribe some tentative subjectivities as part of a feminist response to 'woman inhabiting spaces of absence' (Spivak 10). For many feminists the body is the central site for the inscription of power relations, where the politics of inclusion and exclusion are worked out. Drawing on Joan Scott's assumption that people do not possess experience but are produced by it, I examine the organization, coding, and production of refugee bodies through a number of different discourses. The notion of the body as a map which licenses movement in and out of particular spaces is relevant here. 
Feminist geographers, among others, are keen to trace the markings of bodies and situate them according to what is written on the body.

Refugee camps along the Kenya-Somalia border are complex institutional spaces managed by the United Nations High Commissioner for Refugees (UNHCR). This semi-arid region, home to over 100,000 refugees, is inscribed with its own long history of conflict, racism, and banditry which pervades the camps today. Somali refugees ${ }^{1}$ here endure a political status subordinate to their Kenyan hosts and to the cadre of international professionals who are in place to assist them. This latter cosmopolitan, liberal elite - referred to as the humanitarian international' (African Rights 9) - is comprised of UN employees who carry the coveted light blue laisser passer passports, other expatriate workers, as well as relatively privileged researchers like myself. In contrast, almost all refugees in Kenya are designated prima facie, excluding them from the entitlements of citizenship, access to employment and land. Unlike full, or Convention, status refugees, their political status officially restricts them to the camps through a kind of containment policy established by the Kenyan Government. In some ways, the refugees are less displaced - personally, culturally, geographically - than the relief workers who assist them.

This range of complex subject positions introduces a larger debate among feminists and postcolonial critics: there are those who want to align themselves with the subaltern postcolonial subject and those who insist that such a move becomes only a refined version of the very discourse it seeks to displace. ${ }^{2}$ My own complicity in this matrix of locations and locutions only complicates my telling of them. In an effort to position myself as a feminist author accountable for the political and material conditions of the postcolonial stories which follow, I take seriously Stephen Slemon's warning that 'if we overlook the local, and the political applications of the research we produce, we risk turning the work of our field into the playful operations of an academic glass-bead game, whose project will remain at best a description of global relations, and not a script for their change' (52). In concentrating on encounters between the politically unequal and arguably neo-colonial relationships between stateless refugees and the 'humanitarian international,' I will stake some ambivalent claims about the signification and significance of naming and marking bodies. Refugee sub-citizens, as I will call them, are administered through an institutional framework by the supra-citizens 
who work ostensibly for them. This administration is mediated by the cultural politics of negotiation, subversion, and indifference which mark the spaces of text and territory in the camps. There is plenty of evidence that refugees are counted, contained, and regulated according to coercive codes they sometimes resent and resist.

Refugee relief operations in the camps are organized through an elaborate and exclusive 'radio talk' whereby all of the humanitarian agencies serving refugees - medical, social, legal - communicate by hand-held walkie-talkies. Each organization has its own compound and is named with a 'call sign' based on the 'vocabulary' of international radio code. Thus, staff at the High Commission for Refugees are 'hotels', CARE employees who provide food and social services are 'charlies', the Kenyan police are 'tangos', and so forth. One irony of this network in which an international radio language literally and figuratively maps an intensely local postcolonial field is that there is no call sign or designated name for the refugees whose existence is the very raison d'être of this humanitarian exercise. Edward Said notes of outcast populations that "their existence always counts, though their names and identities do not, they are profitable without fully being there" (64). For Trinh T. Minh-ha, 'naming is part of the human rituals of incorporation, and the unnamed remains less human than the inhuman or sub-human' (1989, 54).

This erasure, one which is exacerbated for refugee women who are less likely than their male counterparts to speak the languages of the 'humanitarian international,' is not incidental. It is perhaps indicative of Judith Butler's poststructuralist distinction between subject and abject beings:

The abject here designates precisely those 'unlivable' and 'uninhabitable' zones of social life which are nevertheless densely populated by those who do not enjoy the status of the subject, but whose living under the sign of the 'unlivable' is required to circumscribe the domain of the subject. (Butler 3)

According to Butler not everything is discursively constructed: 'the limits of constructivism are exposed at those boundaries of bodily life where abjected or delegitimated bodies fail to count as bodies' (Butler 15). Displacement, then, is not only a political reality with material 
consequences, but also 'that which is excluded or marginalized by the construction of a subject position' (Butler 155).

The humanist myth of homogeneity in the 'Great Family of Man' (Barthes 107) could not be more other-worldly in the context of the camps. Despite humanist claims of universalism and inclusion, subject positions are discursively and geographically 'spaced-out.' As I noted above, relief workers are represented through agency affiliation and call sign. Refugees, on the other hand, are numbered, both by ration card and grid location in the camps. ${ }^{3}$ Census-taking exercises, known as 'headcounts', are elaborate in their institutional markings and counting procedures, including the use of indelible ink and wristbands distributed under military supervision inside 'enclosures' constructed specifically for the branding exercise. Historically headcounts have been problematic for UNHCR and other administering agencies. Refugees have not passively subjected themselves to these regimes of regulation. In one camp Sudanese refugees subverted the census process on two occasions, complaining that the rounding up of people into fenced lots was not consistent with basic human respect and reminded them of the days of slavery under Arab rule.

Despite the neo-colonial numbering systems and constellations of institutional power, refugees trade in their own versions of bureaucratic paraphernalia. Ration cards can be purchased in the camp markets, protection letters in Nairobi. Since movement outside the camps is restricted for most refugees, commerce in Kenyan identity cards and UNHCR travel documents is also a lucrative business. Trade in identities may be strategic and even subversive, but many refugees - particularly women - have little access to these goods and services. In contrast to the privileged circles of travelling theory and cultures, refugees in this nominally postcolonial place are going nowhere. Theirs is a culture of containment mitigated by survival strategies and the politics of decolonization. As Trinh has noted: 'The 'needy' cannot always afford to refuse, so they persist in accepting ungratefully. And in persisting, they are led to displace themselves.... Participate or perish.... Displacing is a way of surviving. It is an impossible, truthful story of living in-between regimens of truth' (1990,331-32).

Three texts excerpted from the discursive field of refugee camps are presented below. One is a UNHCR report on refugee management; the 
second is a piece of my own ethnographic work-in-progress based on interviews with women refugees in the three camps; the third is a poem written by a UNHCR international staff member, a woman from Toronto, in response to the cultural politics she faced. In an attempt not to invoke the dangerous empirical authority of 'being there,' I focus my comments on the scenes of enunciation and on the risks involved in citing these texts - particularly the interview and the poem.

The first text comes from the first paragraph of the UNHCR Country Operations Plan:

The reconciliation of data on the refugee population in Kenya has become a priority exercise of the Kenya programme during 1994. The Branch Office has addressed the intractable problem of discrepancies between feeding figures, registered numbers, and total populations, by camp site as well as by overall caseload and nationality, through physical headcounts and registration of refugees in the camps. These discrepancies are due to acts of refugee sabotage; double registration within camps and between camps; and inflation of the number of dependants on ration cards in a bid to maximize their entitlements to food and other relief assistance distributed in the camps. (1)

This is perhaps 'UNese' as its best. UNHCR discursive practices meticulously order the field through the counting, calculating, and coding of refugees who are represented as little more than statistical and moral deviations. 'A centre of ordering,' the organization 'is a place which monitors a periphery, represents that periphery, and makes calculations' (Law 104).

The map of surveillance above tells only one story. In speaking with refugee women at home in their tukuls I ask them to tell another. Producing these texts is wrought with its own problems: how not to authenticate the Native Informant (Spivak); how not to appropriate subjugated knowledges (Haraway); how not to participate in a kind of theoretical tourism in which 'the margin becomes a linguistic or critical vacation, a new poetics of the exotic' (Kaplan cited in Visweswaran 110); how not to reproduce the authoritative Archimedean vantage point nor render transparent the process of translation. ${ }^{4}$ To scrutinize from my position of privilege the conditions of political and discursive displacement expressed in the words and interpretations of a Kenyan-Somali woman is in many ways a politically problematic venture. In spite of 
these cautionary tales which risk paralyzing any attempt at an exchange, I present the following passages as part of an ethnography which aims to hear and make heard some of the silences of refugee women in the camps. The passages mark a movement between cultures, but also between different positions within the discourse of citizenship and nation. Direct contact between the humanitarian international, especially UNHCR officers, and refugees is fairly minimal; similarly, visits like mine to individual refugee huts by a non-Somali outsider disrupt the order of things. While walking from one hut to another, I was asked by one older male refugee if I was a tourist like those unhelpful nurses at MSF (Médecins Sans Frontières), implying in a not-so-subtle way that my presence wasn't very useful. While getting consen $t^{5}$ to conduct over two dozen personal interviews posed no problem, I met secrets, lies, and silences (Visweswaran) along the way. One woman said that she wouldn't tell me her problems because, as a student researcher and outsider, I couldn't do anything about them. Through an interpreter, I asked women what exactly they had done the previous day:

She rises at five to prepare tea and breakfast, tea alone yesterday because there was no wheat flour in the last food distribution. After an hour washing clothes and children, she grinds and mills sorghum for lunch. While lunch is cooking, she goes to look for firewood which takes about three hours. She eats lunch with the family and relaxes until 3:30 when she goes to look for water. She returns two hours later and starts supper which is eaten between seven and 7:30. Then they visit as a family and go to sleep between 8:30 and 9:00.

She awakens at six and has her prayers first. She then prepares tea for the children, washes the utensils, cleans the house and bathes the children until about nine. She collects water, and at about 9:30 starts the process of preparing sorghum for the noon meal. At noon she begins cooking for about an hour; everyone eats at two and then rests. After three, the same grinding of sorghum for the evening meal begins. More water is fetched, and she cooks dinner. The children are fed by eight. She then visits with the neighbours for a while and goes to sleep by nine. (Sometimes her husband collects firewood to sell, but it is dangerous. This woman is part of a group of other women that formed in order to meet additional 
income needs. In a group of about five, each woman contributes an equal portion of her ration after a distribution. The total sum is sold at the market and the money is given to one of the women. The system rotates so that each woman eventually benefits - a rotating credit system).

She rises at six; she has a maid who cooks in the kitchen. Yesterday someone - the husband of pregnant woman - came to her house and asked her to come to Section C5 where the pregnant woman lived. (She has a job with one of the French NGOs as a traditional birth attendant). She stayed there until nine after which she went for help. A vehicle was called to take the woman to the hospital where she gave birth. The traditional birth attendant stayed with her until eleven when she returned to the house. She rested, had lunch, and at three began to build a new tukul (hut) which took about an hour. She built another one today, the one in which we're sitting. They are for the coming hot season and for Ramadhan. At four she returned to work, stayed until six, and then came home. She bathed herself and her kids while the maid cooked. The family ate supper and stayed around the house. At eight they slept.

She is awake by five, lights the fire, and makes tea and food for the family. By seven she leaves to look for firewood - which takes about three hours - and then takes the wood to the market to sell. She returns home by noon, prepares lunch, and takes a bit of rest until three when she goes to fetch water. This also takes three hours because there is a queue. Supper is prepared and the family eats by seven. Up until about nine she talks with her neighbours who lived within the same fenced compound. Then, she is ready for sleeping. The official ration is not enough; she sells firewood to buy extra food.

These texts, mediated through the interpretor and through my own pen, risk dissecting the daily routines of women refugees through individual time-geographies in the same way that some academics have drawn and quartered 'other' cultures (Viswewaran 81). I take this risk with the aim of imagining the lives of these women in such a way that the repetition and duress of their work is felt in the repetition of lean prose. My inten- 
tion is not to count but to enunciate, however problematically, a collaborative 'worlding' (Spivak 2) of lives largely under erasure.

As I noted earlier, face-to-face encounters between sub-citizens and supra-citizens are relatively few in the camps. The author of the third text, a UNHCR Social Services Officer, positions herself carefully. She is of Goan ethnicity and spent the first thirty years of her life as a woman in Pakistan who was part of the Christian minority. An immigrant to Canada in the late 1980s, she has worked as a community organizer and municipal employee in Toronto before taking a contract with UNHCR. She calls herself a feminist. During my stay in the camps, she shared with me this expression of her anger generated at a community consultation with refugee elders, young educated male refugees, CARE and UNHCR staff. In response to queries about why women refugees had been excluded from the consultation when specific requests that they be included had been made, one Somali boy stood up and declared that women were unnecessary and unfit for this type of work. At that point, the woman scratched a poem on a nearby memo pad:

\section{My Son}

Praying in my heart

that somehow

there would be something

about our relationship together

that would make you different

from your brothers

that would teach you

to see me and my sisters

as human

As worthy of love and respect

As capable of receiving

As much as we must give

But

I am a Somali woman

Before I knew what it meant

to be a woman 
the women in my community made sure I would never know the core of me torn away by the power of a rusted blade In the name of culture In the name of religion (What God would have wished this? What God would have wanted his creation so changed?)

All I became is a vessel

A baby machine For your pleasure

Not human

Not animal

An object

For your use

Carrying on the cycle of life maintaining culture maintaining tradition Never knowing how crucial I was to your survival

Only knowing that tomorrow if you have no more use of me

I will be no more

- Jacinta Goveas, September 1994, Hagadera Camp, Kenya

Once again, the discourse of the refugee woman is mediated - this time through an imaginary identification with Somali women on the part of a woman who has spent much of her life in Pakistan. The words of Jacinta Goveas are potent and her feminist politic, strategic. At one moment she demonstrates a solidarity with Somali women as mothers; the next she is critical of the violence genital mutilation invokes on the bodies of these same women. In the first move she privileges the identity of being a 
woman and an insider; in the second she speaks for Somali women but as an outsider, privileging her own apparently less violent culture. To speak as a Somali woman is in some sense to speak for women of that culture-a political move that may raise questions for some feminists. As a Christian, she reiterates the patriarchal personification of a male God. She is sister, outsider, and daughter at once.

In the beautiful domain of philanthropy, we are but one people, without custom, without frontier. ${ }^{6}$

Officially, the job of 'ordering disorder,' of organizing and articulating refugee bodies, belongs to UNHCR in the Kenyan context. The provision of asylum, protection, and assistance as well as records, regulation, and statistics on forced migrants is a professional pursuit engaged in by many well-qualified, competent, well-remunerated individuals. Less officially, the latter texts presented here bridge some of the authoritative distance and unsettle the surveillance technologies, institutional markings, and discursive erasure of refugee women. Butler's analysis of the subject and the abject is one way of casting the supra- and sub-citizens. While both groups are displaced in a social and geographical way when living in the camps, the political construction and 'citizenry' of those who count and those who are counted suggests an allocation of subject positions that is not resoundingly 'universal' or even humanitarian. If refugees in these camps remain under official erasure, even subaltern in some sense, they remain nevertheless 'bodies that matter' (Butler). Gendered, political subjects live and move differentially through authorized and unauthorized circuits of power. As Homi Bhabha provocatively contends, certain groups of people are 'themselves the marks of a shifting boundary that alienates the frontiers of the modern nation' (164), and I would argue, of the Somali nation.

\section{Notes}

I would like to thank Jacinta Goveas for sharing her writing and permitting me to cite her work here. As well, the financial support of SSHRC, the Centre for Refugee Studies at York University, and a research award from the International Development and Research Centre was integral to the development of this text. 
1 There are small numbers of Sudanese and Ethiopian refugees also residing in the camps.

2 This debate is introduced in Ashcroft, Griffiths, and Tiffin, 9.

3 Numbering systems and their application to human bodies are nothing new, as post-Holocaust writing and First Nations histories of incarceration attest to.

4 All interviews were conducted by a female Kenyan interpreter of Somali ethnicity and myself.

5 Consent is a very Western academic notion that suggests power relations are engaged in voluntarily. Those in the camps are well aware that one is outside realms of power.

6 Frederic DeMetz, 1855; cited in Driver.

\section{References}

African Rights 'Humanitarianism Unbound? Current Dilemmas Facing Multi-Mandate Relief Operations in Political Emergencies.' Discussion paper no. 5. London: November 1994.

Anderson, B. Imagined Communities: Reflections on the Origin and Spread of Nationalism. London/NY: Verso, 1991.

Ashcroft, B., G. Griffiths, and H. Tiffin, eds. The post-colonial studies reader. London/New York: Routledge, 1995.

Bammer, A. 'Introduction.' Displacements: Cultural Identities in Question. Bloomington/Indianapolis: Indiana U P, 1994.

Barthes, R. Mythologies London: Paladin, 1957.

Bhabha, H. The Location of Culture. London/New York: Routledge, 1994.

Butler, J. Bodies that Matter: On the Discursive Limits of 'Sex'. London/New York: Routledge, 1993.

Driver, F. 'Discipline Without Frontiers? Representations of the Mettray Reformatory Colony in Britain, 1840-1880.' Journal of Historical Sociology 3.3 (Sept. 1990): 272-293.

Fraser, N. 'Women, Welfare and Politics' in Unruly Practices. Minneapolis: U of Minnesota P, 1989.

Haraway, D. Simians, Cyborgs, and Women: The Reinvention of Nature. New York: Routledge, 1991.

Law, J. Organizing Modernity. Oxford: Blackwell, 1994.

Massey, D. 'Power-geometry and a progressive sense of place.' Mapping the Futures: local cultures, global change. Ed. J. Bird, B. Curtis, T. 
Putnam, G. Robertson, \& L. Tickner. New York: Routledge, 1993. 59-69.

Said, E. Culture and Imperialism. New York: Alfred A. Knopff, 1993.

Spivak, Gayatri Chakravorty. The Postcolonial Critic: Interviews,

Strategies, Dialogues. Ed. S. Harasym. New York/London:

Routledge, 1990.

Trinh T. Minh-ha. 'Cotton and Iron.' Out There: Marginalization and

Contemporary Cultures. Ed. R. Ferguson, M. Gever, Trinh T. Minh-ha, \& C. West. New York: The New Museum of Contemporary Art, 1990.327-36.

-Woman, Native, Other: Writing Postcoloniality and Feminism.

Bloomington and Indianapolis: Indiana UP, 1989.

UNHCR. 'Country Operations Plan - Kenya.' Nairobi: October 1994.

Visweswaran, K. Fictions of Feminist Ethnography. Minneapolis: U of Minnesota P, 1993. 